\title{
ARTICLE \\ Effects of Returning Straw and Milk Vetch on Rice Growth and Greenhouse Gas Emissions
}

\section{Lijin Zhang Guoqin Huang*}

Research Center on Ecological Sciences, Jiangxi Agricultural University, Nanchang, Jiangxi, 330045, China

\begin{tabular}{|c|c|}
\hline ARTICLE INFO & ABSTRACT \\
\hline Article history & \multirow{10}{*}{$\begin{array}{l}\text { The effects of different nitrogen application levels on rice yield and } \\
\text { greenhouse gas }\left(\mathrm{NO}_{2}, \mathrm{CH}_{4} \text { ) emissions from rice fields under the combined }\right. \\
\text { action of straw and milk vetch. Two treatments were set up in the main } \\
\text { area of this experiment: } \mathrm{R}_{0} \text { (no straw returned to the field, } 0 \text { ); } \mathrm{R}_{1} \text { (amount of } \\
\text { straw returned to the field under normal conditions, } 6000 \mathrm{~kg} \cdot \mathrm{hm}^{-2} \text { ). Before } \\
\text { turning the straw back into the field, use a circular knife to cut the straw into } \\
10 \sim 13 \mathrm{~cm} \text {. And } 3 \text { kinds of nitrogen application treatments in the sub-district: } \\
\mathrm{N}_{1} \text { (no nitrogen application, 0), } \mathrm{N}_{2} \text { (nitrogen application, } 15 \mathrm{~kg} \cdot \mathrm{hm}^{-2} \text { ), } \mathrm{N}_{3} \\
\text { (nitrogen application, } 30 \mathrm{~kg} \cdot \mathrm{hm}^{-2} \text { ), two-factor cross-combination,and a non- } \\
\text { nitrogen control CK, total of } 7 \text { treatments. The results showed that in } 2017 \text {, } \\
\text { early rice } \mathrm{R}_{1} \mathrm{~N}_{2} \text { treatment increased the most obvious yield, which was } \\
32.44 \% \text { higher than CK, and late rice } \mathrm{R}_{1} \mathrm{~N}_{1} \text { treatment increased the most } \\
\text { significantly, which was } 17.91 \% \text { higher than } \mathrm{CK}_{\text {. }} \mathrm{CH}_{4} \text { emission is positively } \\
\text { correlated with the straw returned to the field. } \mathrm{N}_{2} \mathrm{O} \text { is the opposite. The } \mathrm{N}_{2} \mathrm{O} \\
\text { emission flux was highest in the treatment of } \mathrm{R}_{1} \mathrm{~N}_{3} \text {, and the } \mathrm{CH}_{4} \text { emission } \\
\text { flux was the highest in the treatment of } \mathrm{R}_{1} \mathrm{~N}_{2} \text {. }\end{array}$} \\
\hline Received: 21 May 2021 & \\
\hline Accented 18 June 2021 & \\
\hline & \\
\hline Published Online: 25 June 2021 & \\
\hline Keywords: & \\
\hline Straw & \\
\hline Milk vetch & \\
\hline Greenhouse gas & \\
\hline Rice yield & \\
\hline
\end{tabular}

\section{Introduction}

Green manure is rich in organic matter and various nutrient elements required by crops, which play an important role in rice, yield and fertility. In recent years, environmental pollution has led to the destruction of the rice field ecosystem. Therefore, it is imperative to protect the ecological environment of the rice field. Straw and milk vetch are good green manure crops in the rice field.

Straw contains organic carbon and various nutrients needed by crops, and it is a rich organic fertilizer. Returning straw and milk vetch can effectively promote the growth of rice.studied the rice yield components, it found Single application of chemical fertilizer, under the conditions of returning straw and milk vetch, it can increase the effective tiller, number of seeds, total number of seeds, seed setting rate and 1000-grain weight of rice, thereby increasing rice yield per unit area ${ }^{[1]}$. Compared with the incineration treatment, straw returning to the field can promote the increase of rice yield to a certain extent, and significantly improve the quality of rice ${ }^{[2]}$ After the straw is returned to the field, applying 15\% chemical nitrogen fertilizer can still increase the yield by $7.2 \%$ compared with conventional $(100 \% \mathrm{~N})$ nitrogen application. The 4 -year test yield of $30 \%$ chemical nitrogen fertilizer reduction still not significantly reduced compared with conventional fertilization ${ }^{[3-4]}$. The $\mathrm{C} / \mathrm{N}$ value of the rice field can relationship with the yield and growth of rice. According to related reports, the combined application of rice straw and milk vetch can increase the

*Corresponding Author:

Guoqin Huang,

Research Center on Ecological Sciences, Jiangxi Agricultural University, Nanchang, Jiangxi, 330045, China;

Email:hgqjxes@sina.com 
yield of rice more than milk vetch or rice straw alone. Increase the number of effective panicle per unit area of rice and the number of tillers and other indicators ${ }^{[5]}$.

Returning straw and milk vetch to the field plays a key role in greenhouse gas emissions from farmland and vital to promote a virtuous cycle of farmland ecosystems. It also one of the effective utilization methods of organic matter such as straw ${ }^{[6-7]}$. The conclusions about the impact of milk vetch on rice field greenhouse gas emissions after returning to the field are not consistent. Some scholars believe that the return of legume green manure to the field promotes the growth of methane bacteria in the rice field and the denitrification of the soil. It has a great promotion effect on the emission of $\mathrm{CH}_{4}$ and $\mathrm{N}_{2} \mathrm{O}$ from the paddy soil ${ }^{[8-9]}$, others believe the milk vetch can replace part of the chemical fertilizer after returning to the field, and reduce the greenhouse gas emissions caused by the application of chemical fertilizer ${ }^{[10-11]}$.

Foods always been a concern of mankind, and it security is one of the three major economic security in the world today. In recent years, with the increase of soil compaction, excessive fertilization and greenhouse effect, the protection of agricultural ecological environment is extremely important. Under the premise of ensuring the stability of food, the development of ecological agriculture is imperative. Therefore, it necessary to carry out research on the carbon-increasing dynamics and greenhouse gas $\left(\mathrm{N}_{2} \mathrm{O}, \mathrm{CH}_{4}\right)$ emission mechanisms under the return of straw and winter-grown milk vetch in the typical rice field ecosystem.

In order to further explore the effects of reduced nitrogen fertilizer application on rice field yield and greenhouse gas emissions under the conditions of returning straw and milk vetch, this experiment adopted the treatment of straw + milk vetch, returning vitis, control, etc. Compared with under the condition of reducing the application of chemical fertilizers, the changes of various indicators during the growth of rice. Compared with conventional fertilization, under the condition of returning straw and milk vetch, reducing nitrogen fertilizer not only reduces the cost of chemical fertilizer application in rice fields, but also greatly improves soil microbes and soil permeability, and indirectly increases rice yield. This research on agricultural production and greenhouse gas emission control has important scientific significance and research value.

\section{Materials and Methods}

\subsection{Experimental Site and Design}

The experiment systematically was conducted from
September 2016 to November 2017 at the experimental field of Deng Jiabu, Yujiang County $\left(116^{\circ} 41^{\prime}\right.$ to $117^{\circ} 09^{\prime}$ E, $28^{\circ} 04^{\prime}$ to $28^{\circ} 37^{\prime} \mathrm{N}$ ) in the subtropical monsoon humid climate with an average annual temperature of $17.6^{\circ} \mathrm{C}$, precipitation of $1741 \mathrm{~mm}$, frost-free period of $258 \mathrm{~d}$, solar radiation of $454.27 \mathrm{~kJ} / \mathrm{cm}^{2}$, and wind speed of 1 to $3.8 \mathrm{~m} /$ s. The average accumulated temperature between $0^{\circ} \mathrm{C}$ and $6586.4^{\circ} \mathrm{C}$. The soil data before the experiment $(0-15 \mathrm{~cm})$ ,are shown in Table 1.

Table 1. Soil data before the experiment

\begin{tabular}{|c|c|c|c|c|c|c|c|}
\hline $\mathrm{pH}$ & $\begin{array}{c}\text { Organic } \\
\text { Matter }\end{array}$ & Available N & Available $\mathbf{P}$ & Available K & Total N & Total P & Total K \\
\hline 5.59 & $34.7 \mathrm{~g} \cdot \mathrm{kg}^{-1}$ & $59.8 \mathrm{~g} \cdot \mathrm{kg}^{-1}$ & $38.0 \mathrm{~g} \cdot \mathrm{kg}^{-1}$ & $151.0 \mathrm{~g} \cdot \mathrm{kg}^{-1}$ & $1.9 \mathrm{~g} \cdot \mathrm{kg}^{-1}$ & $0.5 \mathrm{~g} \cdot \mathrm{kg}^{-1}$ & $22.2 \mathrm{~g} \cdot \mathrm{kg}^{-1}$ \\
\hline
\end{tabular}

In this experiment, there were seven treatments: $\mathrm{R}_{0}$ (no straw returning to the field, 0); R1 (amount of straw returning to the field under conventional conditions, 6000 $\mathrm{kg} \cdot \mathrm{hm}^{-2}$ ), $\mathrm{N}_{1}$ (no nitrogen application, 0), $\mathrm{N}_{2}$ (nitrogen application, $15 \mathrm{~kg} \cdot \mathrm{hm}^{-2}$ ), $\mathrm{N}_{3}$ (nitrogen application, 30 $\mathrm{kg} \cdot \mathrm{hm}^{-2}$ ), total of 6 treatments with two-factor cross combination, and a blank control CK (Table 2). Each plot area is $25 \mathrm{~m}^{2}$, and have protected areas around.

Table 2. Field experimental design.

\begin{tabular}{|c|c|c|c|c|}
\hline Treatment & $\begin{array}{l}\text { Straw retention } \\
\text { Amount }\left(\mathrm{kg}^{\prime} \cdot \mathbf{h m}^{-2}\right)\end{array}$ & $\begin{array}{c}\mathrm{N} 46 \% \\
\text { application of } \\
\text { Chinese milk } \\
\text { vetch }\left(\mathrm{kg} \cdot \mathrm{hm}^{-2}\right)\end{array}$ & $\begin{array}{l}\mathrm{N} \text { application of early } \\
\text { rice }\left(\mathrm{kg} \cdot \mathbf{h m}^{-2}\right)\end{array}$ & $\begin{array}{c}\text { N application } \\
\text { of late rice } \\
\left(\mathrm{kg}^{\prime} \cdot \mathrm{hm}^{-2}\right)\end{array}$ \\
\hline R0N0 & 0 & 0 & 0 & 0 \\
\hline R0N1 & 0 & 0 & 102 & 102 \\
\hline R0N2 & 0 & 15 & 87 & 87 \\
\hline R0N3 & 0 & 30 & 72 & 72 \\
\hline R1N1 & 6000 & 0 & 102 & 102 \\
\hline R1N2 & 6000 & 15 & 87 & 87 \\
\hline R1N3 & 6000 & 30 & 72 & 72 \\
\hline
\end{tabular}

During the experiment, the fertilizers used traditional specifications of urea, calcium, magnesium, phosphorus, and potassium chloride. The ratio of fertilization: nitrogen fertilizer is divided into basal fertilizer, tiller fertilizer and ear fertilizer 6:3:1, and potassium fertilizer is divided into tiller fertilizer and ear fertilizer 7: 3 application, phosphate fertilizer is applied once after transplanting.Nitrogen and phosphorus fertilizer was applied one day before transplanting, tillering fertilizer was applied for five to seven days after transplanting, and panicle fertilizer was applied when the main stem length was 1 to $2 \mathrm{~cm}$. The water management measures of early and late rice growth period were shallow irrigation in the early stage, baking 
in the middle stage and alternation of dry and wet in the later stage. Other management measures were the same as conventional field production.

\subsection{Experiment Materials}

Milk vetch selected local varieties, and in February 2017, the straw of the previous year was chopped and returned to the field in a certain amount. In 2017, the early rice variety was 'Yuenuo 06', and the late rice variety was 'Huarun 2'. Manual transplantation was used to maintain the same number of seedlings in each plot.

\subsection{Rice Yield Measurement}

After the rice matures, 5 representative rice plants are randomly selected from areas with good selectivity. After drying and detaching, test the species, including effective ear, ear length, number of real grains, number of empty grains, 1000-grain weight, real grain weight, empty grain weight and other indicators.

\subsection{Collection and Measurement of Greenhouse Gases}

The experiment uses a static box to collect greenhouse gases. It is composed of a cube of stainless steel with a side length of $50 \mathrm{~cm}$ and the outside is covered with foam and aluminum foil. At the same time, a small fan is installed in the inner part to mix the internal air in order to collect. When the rice grows more than $50 \mathrm{~cm}$, add a layer of $50 \mathrm{~cm}$ cube box (without lid on top and bottom). A base is fixed in the field, and the grooves around the sampling are sealed with water.

After the rice turns green, collect samples at a fixed time every 7 days (8:00-11:00 in the morning), pass through a $50 \mathrm{ml}$ syringe for $0,10,20$, and 30 minutes, and extract about $80 \mathrm{ml}$ of gas through a three-way valve for storage. After being in the vacuum sampling bag, it was quickly brought back to the laboratory for analysis. The collected $\mathrm{N}_{2} \mathrm{O}$ and $\mathrm{CH}_{4}$ greenhouse gases were sent to the laboratory for testing on the same day, and the Agilent 7890B gas chromatography instrument was used for measurement.

\subsection{Data Analysis and Processing}

The gas emission flux was calculated according the equation:

$$
F=p b \frac{d c}{d t} \frac{273}{(273+T)}
$$

Through the above model analysis, calculate the emission fluxes of greenhouse gases $\mathrm{N}_{2} \mathrm{O}$ and $\mathrm{CH}_{4}$ in rice fields.All test data are statistically analyzed and processed by excel2010 and spss26, and graphed by origin.

\section{Results}

\subsection{Rice Yield in Different Treatments}

In 2017, the difference in panicle length between the treatments of early rice and late rice was not significant $(p>0.05)$. Compared with the treatment of straw returning to the field with milk vetch, the average length of the treatment with nitrogen applying milk vetch about $1 \mathrm{~cm}$. In terms of thousand-grain weight, treatment $\mathrm{R}_{1} \mathrm{~N}_{3}$ slighted lower than treatments $\mathrm{R}_{1} \mathrm{~N}_{1}$ and $\mathrm{R}_{1} \mathrm{~N}_{2}$ by $1.33 \%$. According to the data of late rice, under the condition of returning straw to the field,the number of grains per panicle and the total number of grains per panicle under the nitrogen were the most in the treatment of $R_{1} N_{2}$, followed by $\mathrm{R}_{1} \mathrm{~N}_{1}$ and $\mathrm{R}_{1} \mathrm{~N}_{3}$ (Table 3 ).

The treatment $R_{1} N_{2}$ with the highest yield of early rice increased by $32.44 \%$ compared with the treatment $R_{0} \mathrm{~N}_{0}$, had significant effects on it $(\mathrm{P}<0.05)$, and increased by $10.88 \%$ compared with the treatment $\mathrm{R}_{0} \mathrm{~N}_{3}$. The treatment $\mathrm{R}_{1} \mathrm{~N}_{1}$ with the highest yield of late rice increased by $15.19 \%$ compared with the treatment $\mathrm{R}_{0} \mathrm{~N}_{0}$. It shows that under the condition of returning straw to the field, it can effectively promote the increase of rice production. By comparing the yields of different treatments, it can be seen that the more fertilizer is applied, the yield will not be higher, and the amount of nitrogen applied does not have a positive relationship with the yield (Figure 1).

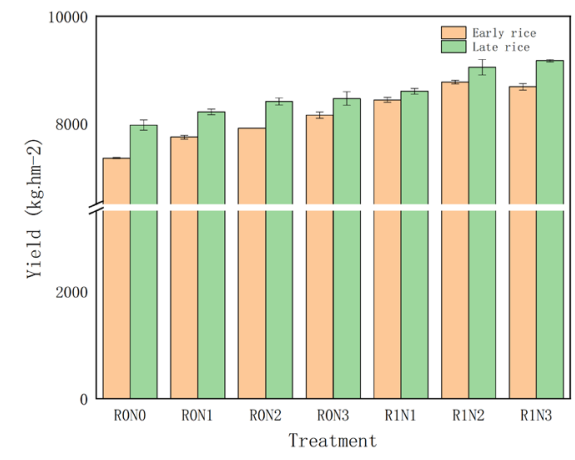

Figure 1. Comparison of rice yields with different treatments

\subsection{Rice Growth Dynamics}

Regardless of early rice or late rice, the rice begins to tiller after turning green in about 7 days when transplanted, tillered rate was the fastest at 16 days after transplanted, and the number of tillers reached the maximum in 30-35 days, until about 65 days, the rice will no longer tiller, and the most tillers are treated with $\mathrm{R}_{1} \mathrm{~N}_{1}$. On the whole, the tillering speed of rice changes from slow to fast, reaches the peak and then begins to decline, 
Table 3. Rice yield and composition factors

\begin{tabular}{|c|c|c|c|c|c|}
\hline Material & Treatment & $\begin{array}{l}\text { Panicle length } \\
\quad(\mathbf{c m})\end{array}$ & $\begin{array}{l}\text { Grain number per spike } \\
\quad\left(\text { No. panicle }^{-1}\right)\end{array}$ & 1000 grain weight $(\mathrm{g})$ & Actual production $\left(\mathrm{kg} \cdot \mathrm{hm}^{-2}\right)$ \\
\hline \multirow{7}{*}{ Early rice } & R0N0 & $20.87 \pm 0.46 \mathrm{~d}$ & $118.67 \pm 1.27 \mathrm{bc}$ & $21.17 \pm 0.21 \mathrm{~cd}$ & $7357.59 \pm 9.5 \mathrm{~g}$ \\
\hline & R0N1 & $22.8 \pm 0.29 \mathrm{c}$ & $132.2 \pm 1.44 \mathrm{a}$ & $21.5 \pm 0.24 \mathrm{bc}$ & $7747.051 \pm 35 f$ \\
\hline & R0N2 & $23.07 \pm 0.12 \mathrm{bc}$ & $119.2 \pm 0.5 \mathrm{bc}$ & $20.7 \pm 0.29 \mathrm{~d}$ & $7916.55 \pm 1.9 \mathrm{e}$ \\
\hline & R0N3 & $22.63 \pm 0.34 \mathrm{c}$ & $122.97 \pm 2.19 \mathrm{~b}$ & $20.9 \pm 0.22 \mathrm{~d}$ & $8158.05 \pm 59.7 \mathrm{~d}$ \\
\hline & R1N1 & $23.67 \pm 0.45 \mathrm{~b}$ & $114.47 \pm 3.81 \mathrm{c}$ & $22.17 \pm 0.3 \mathrm{a}$ & $8440.55 \pm 47 \mathrm{c}$ \\
\hline & R1N2 & $24.63 \pm 0.12 \mathrm{a}$ & $119.4 \pm 1.76 \mathrm{bc}$ & $22.16 \pm 0.41 \mathrm{a}$ & $8771.39 \pm 32.5 b$ \\
\hline & R1N3 & $23.73 \pm 0.29 b$ & $102.77 \pm 2.51 \mathrm{~d}$ & $21.87 \pm 0.25 \mathrm{ab}$ & $8683.95 \pm 62.3 \mathrm{c}$ \\
\hline \multirow{7}{*}{ Late rice } & R0N0 & $21.8 \pm 0.22 \mathrm{c}$ & $126.27 \pm 4.08 \mathrm{~b}$ & $21.53 \pm 0.39 \mathrm{~b}$ & $7972.05 \pm 94.95 \mathrm{e}$ \\
\hline & R0N1 & $22.83 \pm 0.19 \mathrm{~b}$ & $137.17 \pm 3.52 \mathrm{a}$ & $22.17 \pm 0.12 \mathrm{a}$ & $8218.45 \pm 52.5 \mathrm{~d}$ \\
\hline & R0N2 & $23.17 \pm 0.25 \mathrm{~b}$ & $125.8 \pm 1.22 \mathrm{~b}$ & $21.87 \pm 0.34 \mathrm{ab}$ & $8409.85 \pm 65.1 \mathrm{~d}$ \\
\hline & R0N3 & $22.87 \pm 0.25 b$ & $124.27 \pm 4.01 \mathrm{~b}$ & $21.57 \pm 0.17 \mathrm{~b}$ & $8465.5 \pm 126.15 \mathrm{c}$ \\
\hline & R1N1 & $23.90 \pm 0.33 \mathrm{a}$ & $110.43 \pm 8.24 \mathrm{c}$ & $22.4 \pm 0.29 \mathrm{a}$ & $8601.05 \pm 54.9 \mathrm{c}$ \\
\hline & R1N2 & $23.97 \pm 0.29 \mathrm{a}$ & $112.33 \pm 3.65 \mathrm{c}$ & $22.18 \pm 0.21 \mathrm{a}$ & $9049.45 \pm 142.5 b$ \\
\hline & R1N3 & $23.91 \pm 0.36 \mathrm{a}$ & $98.87 \pm 3.48 \mathrm{~d}$ & $22.2 \pm 0.08 \mathrm{a}$ & $9170.15 \pm 23.25 b$ \\
\hline
\end{tabular}

and finally stabilizes. In general, the tiller number of late rice is higher than that of early rice. (Figure 2).

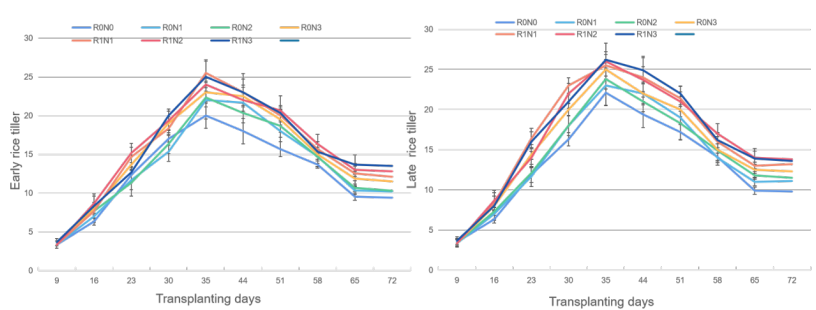

Figure 2. Rice tiller dynamics

Rice plant height grows linearly with the increase of transplanted days, about 25 days after transplanting, and the growth rate is relatively fast from 30 to 55 days, and the rice plant reaches the maximum at 62 days, and tends to stabilize. $\mathrm{R}_{1} \mathrm{~N}_{1}$ are highest, followed by $R_{1} N_{2}$ and $R_{1} N_{3}$, but no significant difference ( $(P>$ 0.05) (Figure 3).
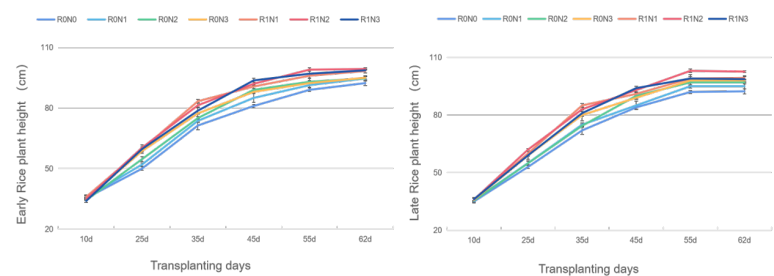

Figure 3. Rice plant height

\subsection{Greenhouse Gas Emissions from Rice Fields}

\subsection{1 $\mathrm{N}_{2} \mathrm{O}$ Emission Flux During the Rice Growing Season}

The $\mathrm{N}_{2} \mathrm{O}$ emission flux is greatly affected by water and fertilization factors, and there are three peaks in the entire growth period of rice: the early rice first $\mathrm{N}_{2} \mathrm{O}$ emission peak appeared on the 18th day after rice transplantation, from $\mathrm{R}_{1} \mathrm{~N}_{2} 、 \mathrm{R}_{1} \mathrm{~N}_{3} 、 \mathrm{R}_{1} \mathrm{~N}_{1}, \mathrm{R}_{0} \mathrm{~N}_{1}, \mathrm{R}_{0} \mathrm{~N}_{2}$ and $\mathrm{R}_{0} \mathrm{~N}_{3}$ treatments 
compared with $\mathrm{R}_{0} \mathrm{~N}_{0}$ treatment, the ratio of increased respectively: $109.39 \%, 74.52 \%, 16.56 \%, 43.22 \%$ 、 $50.87 \%, 58.39 \%$; The second $\mathrm{N}_{2} \mathrm{O}$ emission peak appeared on the 31th day after rice transplantation, $\mathrm{R}_{1} \mathrm{~N}_{2}$ is the highest $17.57 \mu \mathrm{g} \cdot \mathrm{m}^{-2} \mathrm{~h}^{-1}$; The third $\mathrm{N}_{2} \mathrm{O}$ emission peak appeared on the 52th day after rice transplantation $\mathrm{N}_{2} \mathrm{O}$ emission peaks which $\mathrm{R}_{1} \mathrm{~N}_{3}$ is the highest reached 28.55 $\mu \mathrm{g} \cdot \mathrm{m}^{-2} \mathrm{~h}^{-1}$; Late rice straws returned to the field reached a significant level in about 52 days, and the late rice has a small peak on 73th days then stabilized (Figure 4).

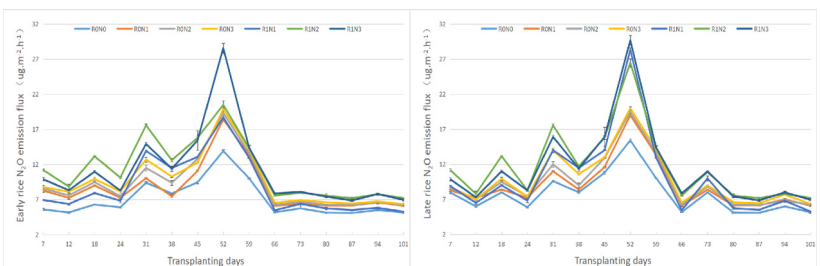

Figure 4. Dynamic changes of $\mathrm{N}_{2} \mathrm{O}$ flux from different treatments

\subsection{2 $\mathrm{CH}_{4}$ Emission Flux During the Rice Growing Season}

During the tiller period, the rice field has sufficient water and suitable temperature, which is helpful for the growth of the methane flora, so the $\mathrm{CH}_{4}$ excretion will increase rapidly. It is seen that the early rice highest $\mathrm{CH}_{4}$ emission flux of $\mathrm{R}_{1} \mathrm{~N}_{2}$ treatment is $16.83 \mu \mathrm{g} \cdot \mathrm{m}^{-2} \mathrm{~h}^{-1}$, there was a small peak around 53 days, but it was relatively small compared with the $\mathrm{CH}_{4}$ emission during the tiller period; Late rice emissions peaked on 24th and 45th days after transplanting, and then decreased, on 81th days appear a small peak.

The $\mathrm{CH}_{4}$ emissions of different treatments decreased during the draining and sunning period. Later, as the temperature increased, the peak of $\mathrm{CH}_{4}$ emissions still appeared during the rice growth, and the $\mathrm{CH}_{4}$ emissions remained at a low level after the sunning period was over until the rice was harvested (Figure 5).
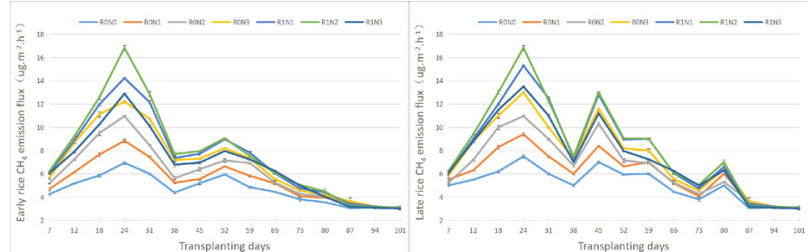

Figure 5. Dynamic changes of $\mathrm{CH}_{4}$ flux from different treatments

\section{Discussion}

\subsection{Effect of Returning Straw to Field on Rice Yield}

Under the conditions of different soil fertility levels, rice needs different fertilizers to obtain high yields. The average yield of rice grains over the past four years is $6.5 \%$ higher than that of the control treatment with only chemical fertilizers ${ }^{[12]}$. Then, many studies have shown that the effect of returning the Chinese milk vetch green manure to the field combined with the application of chemical fertilizers is significant ${ }^{[13]}$. At present, under the conditions of combined application of organic and inorganic fertilizers, a large number of studies have been carried out on rice yield at home and abroad, and the results consistently show that the combined application of organic and inorganic fertilizers significantly increases rice yield compared with single application of chemical fertilizers ${ }^{[14-19]}$. Studies shown under the conditions of milk vetch and chemical fertilizer reduction, rice yield and economic benefits are significantly higher than the yield of single application of chemical fertilizer ${ }^{[20]}$. Among them, the rice yield of milk vetch combined with chemical fertilizer $\mathrm{R}_{1} \mathrm{~N}_{2}$ treatment is different from that of single application. Compared with chemical fertilizers, the economic benefits of rice are significantly improved.

This experimental study shows that returning straw and Chinese milk vetch to the field can increase the yield of rice. The highest yield of $R_{1} N_{2}$ in the treatment of returning straw to the field of early rice was 9744 $\mathrm{kg} \cdot \mathrm{hm}^{-2}$, which was an increase of $32.44 \%$ compared with the control $\mathrm{R}_{0} \mathrm{~N}_{0}$ treatment. The yield of late rice was the highest in the treatment of $\mathrm{R}_{1} \mathrm{~N}_{1}$, which was 9400.05 $\mathrm{kg} \cdot \mathrm{hm}^{-2}$, which was an increase of $15.19 \%$ compared with the control $\mathrm{R}_{0} \mathrm{~N}_{0}$ treatment; The yield of $\mathrm{R}_{0} \mathrm{~N}_{1}$ treated with nitrogen fertilizer for early rice was $7916.55 \mathrm{~kg} \cdot \mathrm{hm}^{-2}$, an increase of $23.08 \%$ compared with the control $\mathrm{R}_{0} \mathrm{~N}_{0}$ treatment, and the yield of $\mathrm{R}_{0} \mathrm{~N}_{1}$ treatment with late rice was $7916.55 \mathrm{~kg} \cdot \mathrm{hm}^{-2}$, an increase of $7.19 \%$. Compared with single application of nitrogen fertilizer under the condition of returning straw to the field, the rice yield increased by $6.3 \%$ on average ${ }^{[21]}$. With the increase of nitrogen application rate, the yield of milk vetch treatment showed a decreasing trend. Under the condition of returning straw to the field, with the increase of nitrogen application rate, there was no higher yield. This is the same as the excessive application of organic fertilizer. Increasing the application of chemical fertilizers cannot achieve the highest yield ${ }^{[22]}$, because the amount of nitrogen fertilizer is not the more the better ${ }^{[23]}$.

\subsection{Farmland Greenhouse Gas Emissions}

$\mathrm{N}_{2} \mathrm{O}$ emissions change seasonally. It usually closely related to the time of fertilization, soil moisture and temperature, and climate parameters. The return of straw and milk vetch to the field increased the $\mathrm{N}_{2} \mathrm{O}$ emission compared with the control. It may that the returning of 
straw and milk vetch provides an energy source for the survival of soil microorganisms, which promotes the increase of soil microbial biomass, while enhancing denitrification also reduces the redox potential, which has a certain impact on soil $\mathrm{N}_{2} \mathrm{O}$ emissions. The results of this experiment showed that compared with the control treatment $\mathrm{R}_{0} \mathrm{~N}_{0}$, both the straw returning to the field and the nitrogen application of milk vetch significantly increased the $\mathrm{N}_{2} \mathrm{O}$ emission from the paddy field ${ }^{[24]}$.

Different regions, different planting methods and management methods will affect the greenhouse gas emissions of crops. The results of this experiment show that rice generally has a relatively large $\mathrm{CH}_{4}$ emission flux during the tiller stage and the late rice flower-filling stage about 15 days after turning green. In the middle and late stages of sunning and maturity, the soil moisture content of the paddy field will obviously decrease, and the oxygen content will increase, so the $\mathrm{CH}_{4}$ emissions will show a downward trend. As with most studies, $\mathrm{CH}_{4}$ emissions are mainly concentrated in the early stage of rice growth ${ }^{[25]}$. The treatment of straw and milk vetch can increase methane $\mathrm{CH}_{4}$ emissions from rice fields. The emission time of early rice is longer than that of late rice, which may be that more rainfall during the growing period of early rice will promote the emission of $\mathrm{CH}_{4}$ gas from rice [26]. However, the $\mathrm{CH}_{4}$ emission flux of late rice is higher than that of early rice, which may be the incomplete decomposition of straw during the early rice period, which promotes the increase of $\mathrm{CH}_{4}$ emissions after the straw decomposes during the late rice period.

\section{Conclusions}

The test results show that returning straw and milk vetch to replace part of the application of chemical fertilizers can promote rice growth and increase yield. Under different nitrogen application conditions, returning rice straw to the field can achieve different degrees of yield increase benefits, which is consistent with the results of She Dongli et al. ${ }^{[27]}$. In 2017, the highest treatment $\mathrm{R}_{1} \mathrm{~N}_{2}$ of early rice yield increased by $32.44 \%$ compared with the control $\mathrm{R}_{0} \mathrm{~N}_{0}$, which significantly different $(\mathrm{P}<0.05)$, and the $\mathrm{R}_{1} \mathrm{~N}_{1}$ treatment of late rice increased by $15.19 \%$. Under the condition of returning straw and milk vetch, it shows that the more chemical fertilizer applied, the higher the yield will not be. When the fertilizer amount reaches a certain level, the rice yield will no longer increase with the increase of $\mathrm{N}$ fertilizer amount. The results showed that the yield of $\mathrm{R}_{1} \mathrm{~N}_{3}$ in early rice and late rice treatments was not the highest. The increase in the yield of early rice is not as large as that of late rice, which may be due to the low temperature of early rice, insufficient fermentation of the straw part, and slow release of fertilizer efficiency, which promotes the late rice more significantly.

The return of straw and milk vetch also has a certain impact on the emission flux of greenhouse gases. The results of this experiment show that the $\mathrm{N}_{2} \mathrm{O}$ and $\mathrm{CH}_{4}$ emissions from the treatments of straw and milk vetch are higher than the control, and the emissions of straw and milk vetch are higher than milk vetch, but the difference is not obvious. $\mathrm{CH}_{4}$ emissions are less in winter fallow fields, and the early and late rice sunning periods are lower than the flooding period. The greater the sunning degree, the more obvious the reduction of $\mathrm{CH}_{4}$ emissions. With the decomposing of straw and suitable temperature, $\mathrm{CH}_{4}$ emissions increase rapidly. The main reason is the production of methanogens and methanobacteria; $\mathrm{N}_{2} \mathrm{O}$ emissions increase with the increase of nitrogen application, which may be related to soil temperature is closely related. Denitrification occurs mainly through the participation of denitrifying bacteria, which leads to an increase in soil temperature. Thereby strengthening soil denitrification and increasing soil $\mathrm{N}_{2} \mathrm{O}$ emissions.

Under the condition of returning straw to the field, reducing the application of nitrogen fertilizer can effectively increase the yield of rice, increase the ability of plants to absorb nutrients, and also have a certain impact on the greenhouse gas emissions of rice fields. In summary, the treatment $R_{1} N_{2}$ has the best effect on increasing rice production and reducing chemical fertilizer, and greenhouse gas emissions in paddy fields.

\section{Acknowledgements}

The authors like to thank the financial support from the National Natural Science Foundation of China (grant number: 41661070), the National Key Research\& Development Program (grant number: 2016YFD0300208) and Jiangxi Province Key Research\& Development Program (grant number: 20161BBF60058).

\section{References}

[1] Lu,p,Shang,Y.,Yang,L.,Han,Y.Effect of Green Manure Rotation on the Change of Nitrogen in Paddy Soil Solution and Rice Yield.soil,2006,03(39):270275.

[2] Liu,W.Research on the Effects of Winter Green Manure and Rice Straw R-eturn on Rice Growth, Soil Properties and Annual Greenhouse Gas Emissions.[Doctoral Dissertation].Wuhan:Huazhong Agricultural University,2015.35.

[3] Chen,D.,Yi,Z.,Zhou,W.,Tu,N..Effects of the amount 
of straw returned to the field on soil nutrients and microorganisms in late rice under different soil tillage methods. Journal of Environmental Science, 2010,08:1722-1728.

[4] Li,J. Effect of straw returning and nitrogen reduction on soil carbon and nitrogen content and crop yield. [Doctoral Dissertation].Xian:Northwest A\&F University, 2013.

[5] Sheng,Y.,Cheng,W.,Zhang,H..Effects of Green Manure and Straw Return on Rice Growth and Yield. Chinese rice,2011,04:27-29.

[6] Zhao,Z,Yue,Y.,Zhang,Y,Lu,X.,Cao,L..Effects of Different Fertilization Conditions on the Characteristics of Greenhouse Gas Emissions in Rice Fields.Journal of Agricultural Environmental Sciences.2014,33(11 ):2273-2278.

[7] Su,X.,Sun,W.,Wang,Z,etc.Effects of straw returning and chemical fertilizers on soil fertility. Acta Pedologica Sinica.2003,40(4):618-623.

[8] Aulakh,M.,Doran,J.,Waiters,D..Crop residue type and placement effects on gentrification and internalization. SoilSci.Soc. Am. J.,1991,55: 1020-1025.

[9] Galbally,I., Fraser,P., Meyer,C.. Biosphere-atmosphere exchange of trace gases over Australia[A]. In:Gifford RM, Barson M M eds.Australia's Renewable Resources Sustainability and Global Change.Bureau of Rural Resources Proceedings No.14[C].Canberra:AGPS, 1992.117-149.

[10] Hu,L.,Li,L,Chen, F, Ye, T., Yang, G..Effects of Different Cultivation Systems on Methane Emission from Rice Fields in Southern China. Ecosystem,2006,15(6):1216-1219.

[11] Zhu, B,Yi,L.,Hu,Y.,Zeng,Z., Tang,H.,Xiao, X., Y ang,G..Effects of fresh ryegrass return to field on fertilizer nitrogen cycle in double-cropping paddy fields.Chinese Agricultural Sciences,2012, 45(13):2764-2770.

[12] Xiong,Z.,Xing,G.,He,T.,.,Shi,S.,Sheng,G.,Du,L.. Study on the contribution of legume green manure and fertilizer nitrogen to nitrous oxide emission from double-cropping paddy fields.Acta Pedologica Sinica,2003,40(5):704-710.

[13] Wang,F,Lin,C,Lin,X.,He,C.,Li,Q.,Li,Y,Huang,G .,Zhong,S..The effect of contin-uous pressing of milk vetch on the yield of Fujian single-cropping rice and the absorption, distribution and residual of fertilizer nitrogen.Journal of Plant Nutrition and Fertilizer,2014,04:896-904.

[14] Xu,C.,Xie,Z.,Xu,Z., etc.Effects of chemical fertilizer application on nutrient absorption and dry matter accumulation of early rice under the same amount of milk vetch.Journal of Jiangxi Agriculture,2010(10):13-14.

[15] Zhou,X,Li,Z.,Xie,J,etc. Effects of reduced chemical fertilizer application on r-ice yield, output value and soil carbon and nitrogen content after utilizati-on of milk vetch.Agricultural Science \& Technology, 2015(02):266-271.

[16] Wang,S.,Zhu,H.,Tang,S,etc.Effects of Combined Application of Milk Vetch and Chemical Fertilizers on Soil Biological Properties in Double-cropping Rice Regions along the Yangtze River in Anhui.Journal of Plant Nutrition and Fertilizer,2015(02):387-395.

[17] Zhong,X.,Luo,Q..Effect of Milk vetch on Soil Physical and Chemical Prop-erties and Rice Yield. Modern Agricultural Technology,2015(06):222-230.

[18] Zhou,L., Ye,H.,Li,D., etc.Effect of combined application of organic fertilizers on fertilization of gledding paddy soil. China Soil and Fertilizer,2016(01):89-93.

[19] Huang,T,Wang,C.,Xu,L.,etc.Effect of Chinese Milk Vetch Returning to Field for Two Years on Rice Yield and Soil Fertility.Shanghai Agricultural Science and Technology,2016(01):103-104.

[20] Yang,B.,Huang,G.,Wang,C,etc.Effect of Winter Planting of Green Manure in Paddy Field on Rice Yield and Soil Fertility.Chinese Journal of EcoAgriculture,2013(10):1209-1216.

[21] Zhang,S..Effect of Returning Milk Vetch into the Field and Reducing the Application of Chemical Fertilizer on Rice Yield.Fujian Agricultural Science and Technology,2011(04):75-77.

[22] Zhao,D, Yan,T.,Qiao,J,etc.Depth reduction effect of nitrogen fertilizer under the mode of returning green manure to field in Taihu Lake area.Journal of Applied Ecology,2015(06):1673-1678.

[23] Wang,S.,Huang,Q.,Xu,M.,etc.Variation characteristics of nitrogen fertilizer recovery rate of double-cropping rice in red paddy soil under long-term different fertilization conditions.Journal of Plant Nutrition and Fertilizer,2013(02):297-303.

[24] Tang,H.,Xiao,X., Shuai,X., Tang,W.,Lin, Y., Tang ,H.,Yang,G..Effects of planting different winter crops in double-cropping rice fields on methane and nitrou-s oxide emissions. Acta Ecologica Sinica,2012,32(5):1481-1489.

[25] Zhou, J.,Huang, Y,Zong,L., Wang, Y., Ronald,L.. Comprehensive effects of differe-nt types of organic fertilizers on $\mathrm{CH}_{4}$ and $\mathrm{N}_{2} \mathrm{O}$ emissions from rice fields. Environmental science,2003a,24(4):7-12.

[26] Peng,S., Yang, S.,Xu,Z..The effect of controlled irrigation on the comprehensi-ve emission of $\mathrm{CH}_{4}$ and $\mathrm{N}_{2} \mathrm{O}$ and the greenhouse effect of rice fields. Prog-ress in Water Science,2010,21(2):235-240.

[27] She,L.,Wang,K.,Xie,X.,Chen,M,Lin,W.,Study on soil fertility and yield effects of returning rice straw to the field.Chinese Journal of Eco-Agriculture, 2008,16(1):100-104. 